\title{
Dinosaurs and scientific inquiry
}

Daniel E. Barta

Acta Palaeontologica Polonica 66 (2), 2021: 436-436 doi:http://doi.org/10.4202/app.00898.2021

Mary Higby Schweitzer, Elena Rita Schroeter, Charles Doug Czajka 2021. Dinosaurs: How We Know What We Know. 547 pp. CRC Press, Taylor and Francis Group. ISBN: 978-0-367-56381-3. Price USD 79.96 (paperback); eBook USD 79.96.

Daniel E. Barta [daniel.barta@okstate.edu], Department of Anatomy and Cell Biology, Oklahoma State University College of Osteopathic Medicine at the Cherokee Nation, Tahlequah, Oklahoma, USA.

This is an open-access article distributed under the terms of the Creative Commons Attribution License (for details please see creativecommons.org), which permits unrestricted use, distribution, and reproduction in any medium, provided the original author and source are credited.

Fofif Full text $(237.5 \mathrm{kB})$ 